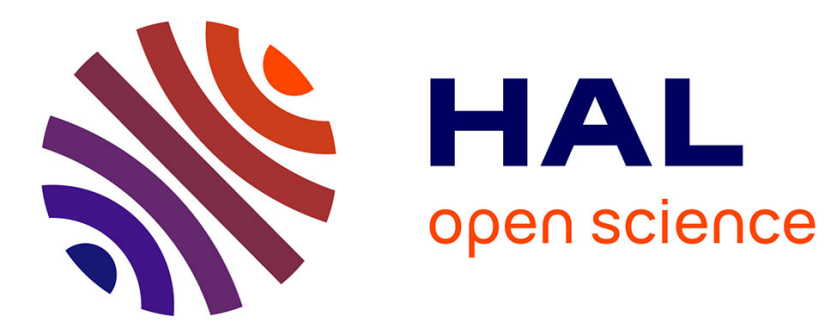

\title{
Does the SLC40A1 gene modify HFE-related haemochromatosis phenotypes?
}

\author{
Albert Altès, Vanessa Bach, Angels Ruiz, Anna Esteve, Angel F. Remacha, \\ M. Pilar Sardà, Jordi Felez, Montserrat Baiget
}

\section{- To cite this version:}

Albert Altès, Vanessa Bach, Angels Ruiz, Anna Esteve, Angel F. Remacha, et al.. Does the SLC40A1 gene modify HFE-related haemochromatosis phenotypes?. Annals of Hematology, 2008, 88 (4), pp.341345. 10.1007/s00277-008-0590-9 . hal-00477976

\section{HAL Id: hal-00477976 https://hal.science/hal-00477976}

Submitted on 30 Apr 2010

HAL is a multi-disciplinary open access archive for the deposit and dissemination of scientific research documents, whether they are published or not. The documents may come from teaching and research institutions in France or abroad, or from public or private research centers.
L'archive ouverte pluridisciplinaire HAL, est destinée au dépôt et à la diffusion de documents scientifiques de niveau recherche, publiés ou non, émanant des établissements d'enseignement et de recherche français ou étrangers, des laboratoires publics ou privés. 


\title{
Does the SLC40A1 gene modify HFE-related haemochromatosis phenotypes?
}

\author{
Albert Altès • Vanessa Bach • Angels Ruiz • \\ Anna Esteve • Angel F. Remacha • M. Pilar Sardà • \\ Jordi Felez $\cdot$ Montserrat Baiget
}

Received: 4 June 2008 /Accepted: 31 July 2008 /Published online: 27 September 2008

(C) Springer-Verlag 2008

\begin{abstract}
Most hereditary haemochromatosis patients are homozygous for the C282Y mutation of the HFE gene. However, the phenotypic expression and clinical aggressiveness of the disease differs considerably from patient to patient. The main objective of this work was to study the role of variants in the SLC40A1 gene in the severity of iron overload and his clinical consequences in 100 Spanish probands homozygous for the $\mathrm{C} 282 \mathrm{Y}$ mutation of the HFE gene. We performed automated sequencing of the coding regions, including intron-exon junctions of the SLC40A1 gene. We studied the association between polymorphisms in the SLC40A1 gene and median values of iron removed, taking into account statistical corrections for multiple comparisons. No pathogenic mutations in the SLC40A1 were detected. Five known single nucleotide polymorphisms (SNPs) were identified, and two of them were associated with phenotypic characteristics. IVS1-24 C $>\mathrm{G}$ was associated with the amount of iron removed and presence of liver disease: Of the 83 patients finally studied for this SNP, the amount of iron removed was above the median in 36 of $56(64.3 \%)$ for $\mathrm{C} / \mathrm{C}$, in nine of $23(39.1 \%)$ for $\mathrm{C} / \mathrm{G}$ and in zero of four $(0 \%)$ for $\mathrm{G} / \mathrm{G}$ patients $(P=0.01)$. Liver damage was observed in 34 of 56 patients $(60.7 \%)$
\end{abstract}

\footnotetext{
A. Altès $(\bowtie) \cdot A$. Ruiz $\cdot$ A. Esteve

Servei Hematologia, ALTHAIA,

Flor de Lis 33,

08242 Manresa, Spain

e-mail: aaltesh@althaia.cat

V. Bach $\cdot$ J. Felez

A.B.S. Canaletes, Hospital de Sant Pau,

Barcelona, Spain
}

A. F. Remacha • M. P. Sardà · M. Baiget

Hematology and Genetics Departments, Hospital de Sant Pau, Barcelona, Spain for $\mathrm{C} / \mathrm{C}$, in eight of 23 (34.8\%) for $\mathrm{C} / \mathrm{G}$ and in zero of four $(0 \%)$ for $\mathrm{G} / \mathrm{G}(P=0.01)$. Both associations remained significant at multivariate analysis $(P=0.011$ and $P=$ 0.023 , respectively). IVS1-24 C>G on the ferroportin gene seems to be a genetic modifier for clinical aggressiveness of HFE1 haemochromatosis.

Keywords SLC 40A1 · Ferroportin · Haemochromatosis . Genetic penetrance $\cdot$ Iron metabolism

\section{Introduction}

Hereditary haemochromatosis $(\mathrm{HH})$ is an inherited disorder of iron metabolism. It is characterised by inappropriate dietary iron absorption leading to a progressive accumulation of iron in tissues. Iron overload may cause liver, heart and pancreas damage during middle age or thereafter. As the disease progresses, patients can develop liver cirrhosis, diabetes, heart disease and, sometimes, death [24]. Most $\mathrm{HH}$ patients (type $1 \mathrm{HH}$ ) are homozygous for a missense mutation (C282Y) in the gene HFE, located on 6p22.1, that disrupts the conformation of an atypical major histocompatibility class I molecule [12, 18]. In Spain, $0.1 \%$ of people are homozygous for this mutation [3, 27]. However, the penetrance of the disease in subjects with the YY genotype is not complete [2,7], and a number of studies have demonstrated high prevalence and low morbidity of type 1 hereditary haemochromatosis $[1,5,28]$.

Additional genetic and environmental factors may contribute to differential expression of C282Y homozygosity [7]. Diet, alcohol, blood donations and viral hepatitis are known environmental factors that can modify the clinical presentation of haemochromatosis, but less information is available about the impact of putative genetic modifiers. From 2000 to 
2004, some non-HFE-related forms of haemochromatosis were identified, and these rare conditions were successively related to mutations in the genes that encode transferrin receptor 2 (TFR2) [9], ferroportin 1 (SLC40A1) [25], hepcidin (HAMP) [26] and haemojuvelin (HJV) $[15,23]$. Later, some articles described a digenic mode of inheritance of the disease that definitively altered the monogenic perception of haemochromatosis [13, 14, 19].

The main objective of this study was to determine the influence of variants in the SLC40A1 gene on the amount of iron removed by phlebotomies of homozygotes for the $\mathrm{C} 282 \mathrm{Y}$ in a clinically well-defined group of 100 Spanish $\mathrm{HH}$ probands. Subsequently, we studied the relationship of clinical characteristics only with genetic variants related with iron overload.

\section{Materials}

All patients selected for this study were referred to the haematologist for biochemical evidence of iron overload, with or without symptoms compatible with genetic haemochromatosis. Transferrin saturation and serum ferritin were measured at diagnosis by standard methods in samples obtained after an overnight fast. In those patients with a transferin saturation index $\geq 55 \%$ or a serum ferritin level $\geq 400 \mu \mathrm{g} / \mathrm{l}$ on two occasions, HFE mutations were analysed using the LightCycler equipment [3] (Roche Diagnostics Gmbh, Mannheim, Germany). Finally, 100 non-related homozygous $\mathrm{C} 282 \mathrm{Y}$ patients were included in the study. All patients were diagnosed between 1985 and 2005. In all patients, the total amount of iron removed was calculated as the number of phlebotomies (with $450 \mathrm{ml}$ of blood drawn at each session) multiplied by 0.2 (the number of grams of iron removed per session). In some patients, the hepatic iron concentration and the hepatic iron index were determined as previously described [6]. All patients gave their written informed consent to participate in the study, in accordance with the protocol validated by the ethics committee at Sant Pau Hospital.

Definition of clinical complications To study the association between genetic polymorphisms and body iron stores, the median value of iron removed by phlebotomies and the median value of serum ferritin were used as threshold. To evaluate the clinical severity of the disease in each patient, we considered only two clinical complications classically related with haemochromatosis: presence of liver damage and diabetes. Liver damage was diagnosed when aspartate aminotransferase and alanine transaminase enzymes were above normal limits at least twice at intervals of over 3 months or when there was histological evidence of liver fibrosis/cirrhosis. Patients considered diabetic were those receiving treatment for diabetes and those with a fasting plasma glucose test $\geq 126 \mathrm{mg} / \mathrm{dl}$ on two occasions. Alcohol consumption was assessed from patient history, and $>80 \mathrm{~g} / \mathrm{d}$ of ethanol was considered excessive. Viral serology data for hepatitis $\mathrm{B}$ and $\mathrm{C}$ were available in all patients.

\section{Mutational analysis}

Genomic DNA was extracted from peripheral blood leukocytes by use of FlexiGene DNA kit (Qiagen, West Sussex, UK) according to the manufacturer's instructions. Mutation detection was performed by polymerase chain reaction (PCR) amplification of each of the eight coding exons of FPN1 (GeneBank No NM-014585) including intron-exon junctions. The oligonucleotide primers used for PCR amplification of FPN1 exons and intron-exon junctions and the PCR conditions have been previously described $[21,29]$. After purification with Qiaquick ${ }^{\circledR}$ PCR purification kit (Qiagen), PCR products were subjected to bidirectional direct cycle sequencing using the BigDye ${ }^{\circledR}$ Terminator v1.1 cycle sequencing kit (Applied Biosystems, Warrington, UK) and an Abi3100-Avant genetic analyzer (Applied Biosystems). Sequencing primers were the same as those used for PCR amplification.

Statistical analyses A chi-square test was used to study univariate relationships between the presence of genetic polymorphisms and iron removed above or below the median value. To do this comparison, we applied the Bonferroni correction for multiple comparisons (five genetic variants for one clinical trait), and for this reason, only $P$ values of $<0.01$ were considered statistically significant in this case. We only studied other phenotype traits (ferritin above or below median value and presence/ absence of liver disease or diabetes) in relation with genetic variables associated with iron overload. A logistic regression model was adjusted for sex, age, alcohol abuse and a positive hepatitis serology to study the association of iron overload with genetic characteristics.

\section{Results}

Biochemical and clinical characteristics of the whole cohort have been described in detail elsewhere [4]. In summary, there were 73 males and 27 females with a median age of 45 years (range 16-73). Fourteen patients consumed more than $80 \mathrm{~g}$ /day of alcohol, and three had a positive serology for hepatitis $\mathrm{C}$ virus. The median ferritin of the whole group was $861.5 \mu \mathrm{g} / \mathrm{l}$ (range 17-10,000), and the median of iron removed by phlebotomy was $4.25 \mathrm{~g}$ (range $0.5-20$ ). The iron removed was $\geq 5 \mathrm{~g}$ in 43 patients. Forty-four patients 
presented with liver damage, and a liver biopsy was performed in 33 of them. Fibrosis-cirrhosis of the liver was finally diagnosed in 28 and liver cancer in four. Twenty-four individuals had diabetes. Table 1 summarises the biochemical characteristics of this cohort.

\section{SLC40A1 gene mutations}

Five polymorphisms in SLC40A1 gene were studied. (Fig. 1). Three of them were located in the 5'UTR flanking the iron-responsive element. Two were single nucleotide polymorphisms (SNPs), a $\mathrm{C}>\mathrm{G}$ at $\mathrm{nt}-8$ (5'UTR-8) and a $\mathrm{G}>\mathrm{C}$ at nt-98 (5'UTR-98) relative to the start of the translation. The third was a CGG microsatellite repeating seven to nine times $5 \mathrm{nt}$ upstream of the start of transcription. Another $\mathrm{C}>\mathrm{G}$ change was located in intron 1, $24 \mathrm{nt}$ upstream of the start of exon 2 (IVS1-24). The last SNP studied was a C $>$ T change of $\mathrm{nt} 663$ in exon 6 (Ex $6 \mathrm{nt}$ 663), without consequences in the final amino acid composition of the protein (V221V). We only found a clear relationship between the SNP IVS1-24 C>G and the amount of iron removed. Table 2 summarises the relationships found between this genetic polymorphism and clinical variables. These relationships are explained in detail on continuation.

We were able to study 83 patients for IVS1-24 C>G polymorphism. Fifty-six of them were $\mathrm{C} / \mathrm{C}, 23$ were $\mathrm{C} / \mathrm{G}$ and four were $\mathrm{G} / \mathrm{G}$. Of 56 patients with a $\mathrm{C} / \mathrm{C}$ genotype, 36 $(64.3 \%)$ had an amount of iron removed above the median. Nevertheless, only nine of 23 of $\mathrm{C} / \mathrm{G}$ patients $(39.1 \%)$ and zero of four of $\mathrm{G} / \mathrm{G}$ patients $(0 \%)$ had levels of iron removed above the median $(P=0.01)$. This association remained significant in a logistic regression model adjusted for age and sex $(P=0.01)$. The risk of having a level of iron removed above the median in $\mathrm{C} / \mathrm{C}$ patients was 4.7 times higher than in the $\mathrm{C} / \mathrm{G}$ or $\mathrm{G} / \mathrm{G}$ patient groups (IC 95\%, 1.415.8). A similar association was observed between this genetic parameter and the presence of liver damage. Effectively, 34 of $56(60.7 \%) \mathrm{C} / \mathrm{C}$ patients, eight of 23 (34.8\%) $\mathrm{C} / \mathrm{G}$ patients and zero of four $(0 \%) \mathrm{G} / \mathrm{G}$ patients

Table 1 Biochemical characteristics of the cohort of 100 homozygous C282Y patients

\begin{tabular}{lccc}
\hline Parameter & Mean & Median & Range \\
\hline Tranferrin saturation & $82 \%$ & $84 \%$ & $30-161 \%$ \\
Ferritin $(\mu \mathrm{g} / \mathrm{l})$ & 1259 & 861 & $17-10,000$ \\
Iron removed $(\mathrm{g})_{\text {Liver iron concentration }^{\mathrm{a}}(N=22)}$ & 5.5 & 4.2 & $0.5-20$ \\
Hepatic iron index $^{\mathrm{b}}(N=22)$ & 4.6 & 192 & $21-456$ \\
\hline
\end{tabular}

${ }^{\mathrm{a}} \mu \mathrm{mol} / \mathrm{g}$ liver dry weight

${ }^{b}(\mu \mathrm{mol} / \mathrm{g}$ liver dry weight $) /$ age in years

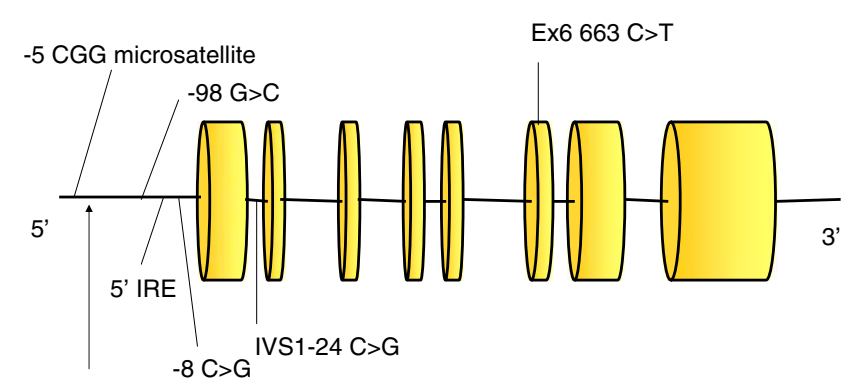

Start of transcription

Fig. 1 SLC40A1 (ferroportin) gene and location of polymorphisms studied

had liver damage $(P=0.01)$. After adjusting for age, sex, alcoholism and presence of diabetes, this variable remained significant $(P=0.023)$. The risk of having liver damage was 4.5 times higher in $\mathrm{C} / \mathrm{C}$ patients than in the other genotypes (IC 95\%, 1.2-16.7). Finally, although more patients with the $\mathrm{C} / \mathrm{C}$ genotype had a level of ferritin above the median $(31 / 56,55.4 \%)$ than $\mathrm{C} / \mathrm{G}-\mathrm{G} / \mathrm{G}$ patients $(12 / 27,44.4 \%)$, this difference was not statistically significant. Presence of IVSI-24 $\mathrm{C}>\mathrm{G}$ SNP was not statistically related with the presence of diabetes.

In view of these results, we determined this SNP in a control population (blood donors) of 87 individuals, 41 men and 46 women, with a median age of 40 years (range 23-81). Sixty-four individuals were $\mathrm{C} / \mathrm{C}(73.6 \%), 22$ were $\mathrm{C} / \mathrm{G}(25.3 \%)$ and only one was $\mathrm{G} / \mathrm{G}(1.1 \%)$, and their ferritin levels did not differ statistically. The allelic frequency of the allele $G$ in this control population was $22 / 174=0.14$, similar to that found in the group of patients with a high level of iron removed $(9 / 90=0.1, P=0.52)$. Nevertheless, the allelic frequency of allele $\mathrm{G}$ among the group of C282Y homozygous patients with a low level of iron $(22 / 76=0.29)$ was significantly higher than in controls $(P=0.002)$.

Table 2 Statistically significant relationships between genetic polymorphisms on SLC40A1 gene and selected clinical variables

\begin{tabular}{llll}
\hline & \multicolumn{2}{l}{ IVS1-24 } & \\
\cline { 2 - 4 } & $\mathrm{C} / \mathrm{C}$ & $\mathrm{C} / \mathrm{G}$ & $\mathrm{G} / \mathrm{G}$ \\
\hline Iron removed & & & \\
Below median & $20(35.7 \%)$ & $14(60.9 \%)$ & $4(100 \%)$ \\
Above median & $36(64.3 \%)$ & $9(39.1 \%)$ & $0(0 \%)$ \\
Total & 56 & 23 & 4 \\
Liver damage & & & $4(100 \%)$ \\
No & $22(39.3 \%)$ & $15(65.2 \%)$ & $0(0 \%)$ \\
Yes & $34(60.7 \%)$ & $8(34.8 \%)$ & 4 \\
Total & 56 & 23 & \\
\hline
\end{tabular}

$P=0.01$ 


\section{Discussion}

One of the most significant recent findings relative to iron metabolism is the evidence that peptide hepcidin is the central regulator of inorganic iron absorption [22]. This peptide exerts its function by interacting with the iron transporter ferroportin by means of a recently uncovered mechanism [10, 11]. In general, primary iron overload disorders are due to a decrease in hepcidin action that enables increased iron absorption from the intestine and increased export to plasma from macrophages, both mechanisms mediated by an upregulation of ferroportin function. More than 20 autosomal dominant mutations in the ferroportin gene have been described as a cause of haemochromatosis in clinical practice (type IV), providing further evidence of the importance of this protein in iron metabolism. The pivotal role of ferroportin in iron metabolism justifies our interest in searching for relatively frequent polymorphic variations in this gene and studying the impact of these genetic forms in the expression of haemochromatosis disease in homozygous $\mathrm{C} 282 \mathrm{Y}$ patients. Theoretically, minor changes in expression or function of ferroportin may lead to significant differences in iron overload among haemochromatosis patients. To validate this hypothesis, we performed a mutational analysis of the SLC40A1 gene in a group of $100 \mathrm{C} 282 \mathrm{Y}$ homozygous patients. This cohort was very informative because clinical data about the presence or not of liver disease and diabetes were available for all patients and because the amount of iron in each patient was calculated by quantitative phlebotomy. This procedure is more accurate than other surrogate markers such as ferritin level. In our group of patients, the SNP IVS1-24 $C>G$ was an independent predictor of the severity of iron overload and the appearance of liver disease in univariate and multivariate analyses. Moreover, the allelic frequency of the $\mathrm{G}$ allele in $\mathrm{C} 282 \mathrm{Y}$ homozygous patients with "low" levels of body iron was higher than in controls. It would seem that the G allele "protects" patients against iron overload. This SNP do not seem to alter ferritin levels in control population and its role may be circumscribed to pathological conditions.

This SNP has only been studied once previously, by the Ernest Beutler group in the context of haemochromatosis and iron overload [16]. They studied a group of $14 \mathrm{C} 282 \mathrm{Y}$ homozygous patients, eight with a significant iron overload and six without. Interestingly, the $G$ allele frequency was 0.19 in the group with iron overload and 0.25 in the group without it. Although differences in these allelic frequencies were not significant, this could be due to the low number of patients studied. Nevertheless, these results support our finding that the G allele in this SNP is associated with a lower iron burden. This polymorphism is associated with iron burden and liver disease, but not with the presence of diabetes, and this fact reinforces our previous impression that diabetes is not directly related with iron overload in haemochromatosis as was previously thought [4].

A mitochondrial polymorphism has been observed more frequently in $\mathrm{C} 282 \mathrm{Y}$ homozygotes with haemochromatosis than in non-expressing C282Y homozygotes [17], but this association was not confirmed in other studies [8]. Another group has recently performed a study for relatively frequent variants (as opposed to the rare mutations already known) in genes that can modify serum ferritin levels in C282Y homozygotes [20]. They studied 81 SNPs in ten candidate genes selected from the CEU HapMap database in a large cohort of 592 subjects. They detected a significant association between serum ferritin levels and rs235756, a common SNP in the BMP2 genic region. The biological nature of this statistical association remains undefined.

How can this IVS1-24 SNP, located in a non-translated region, affect iron overload and the appearance of liver disease? Unfortunately, we do not have a clear answer to this question. We do know, however, that this SNP does not create a codon stop. Nevertheless, its location within the 50 nt region upstream to the start of exon 2 could affect the splicing machinery and the functional expression of exon 2 . It is clear that further studies are necessary to validate the effect of this polymorphism on iron load and liver disease in haemochromatosis patients.

Acknowledgements This work was partially supported by grants from Fondo de Investigaciones Sanitarias (PI-04/1120) and Agencia d'Avaluació de Tecnología i Recerca Mèdica (005/29/2004).

\section{References}

1. Adams PC, Reboussin DM, Barton JC, McLaren CE, Eckfeldt JH, McLaren GD, Hemochromatosis and Iron Overload Screening (HEIRS) Study Research Investigators et al (2005) Hemochromatosis and iron-overload screening in a racially diverse population. N Engl J Med 352:1769-1778 doi:10.1056/NEJMoa041534

2. Allen KJ, Gurrin LC, Constantine CC, Osborne NJ, Delatycki $\mathrm{MB}$, Nicoll AJ et al (2008) Iron-overload-related disease in HFE hereditary hemochromatosis. N Engl J Med 358:221-230 doi:10.1056/NEJMoa073286

3. Altes A, Ruiz A, Barceló MJ, Remacha AF, Puig T, Maya AJ et al (2004) Prevalence of C282Y, H63D and S65C mutations of HFE gene in 1146 newborns from a region of Northern Spain. Genet Test 8:407-410 doi:10.1089/gte.2004.8.407

4. Altes A, Ruiz A, Martinez C, Esteve A, Vela MD, Remacha AF et al (2007) The relationship between iron overload and clinical characteristics in a Spanish cohort of 100 C282Y homozygous hemochromatosis patients. Ann Hematol 86:831-835 doi:10.1007/ s00277-007-0336-0

5. Asberg A, Hveem K, Thorstensen K, Ellekjter E, Kannelønning $\mathrm{K}$, Fjøsne $U$ et al (2001) Screening for hemochromatosis: high prevalence and low morbidity in an unselected population of 65,238 persons. Scand J Gastroenterol 36:1108-1115 doi:10.1080/ 003655201750422747 
6. Barry M, Sherlock SA (1971) Measurements of liver-iron concentration in needle-biopsy specimens. Lancet 1:100-103 doi:10.1016/S0140-6736(71)90838-5

7. Beutler E, Felitti VJ, Koziol JA, Ho NJ, Gelbart T (2002) Penetrance of 845-A (C282Y) HFE hereditary haemochromatosis mutations in USA. Lancet 359:211-218 doi:10.1016/S0140-6736(02)07447-0

8. Beutler E, Beutler L, Lee PL, Barton JC (2004) The mitochondrial nt 16189 polymorphism and hereditary hemochromatosis. Blood Cells Mol Dis 33:344-345 doi:10.1016/j.bcmd.2004.06.006

9. Camaschella C, Roetto A, Cali A, De Gobbi M, Garozzo G, Carella M et al (2000) The gene TFR2 is mutated in a new type of haemochromatosis mapping to 7q22. Nat Genet 25:14-15 doi: $10.1038 / 75534$

10. De Domenico I, Ward DM, Kaplan J (2007) Hepcidin regulation: ironing out the details. J Clin Invest 117:1755-1758 doi:10.1172/ JCI32701

11. De Domenico I, Ward DM, Langelier C, Vaughn MB, Nemeth E, Sundquist WI et al (2007) The molecular mechanism of hepcidinmediated ferroportin down-regulation. Mol Biol Cell 18:25692578 doi:10.1091/mbc.E07-01-0060

12. Feder JN, Gnirke A, Thomas W, Tsuchihashi Z, Ruddy DA, Basava A et al (1996) A novel MHC class I-like gene is mutated in patients with hereditary haemochromatosis. Nat Genet 13:399408 doi:10.1038/ng0896-399

13. Jacolot S, Le Gac G, Scotet V, Quere I, Mura C, Ferec C (2004) HAMP as a modifier gene that increases the phenotypic expression of the HFE pC282Y homozygous genotype. Blood 103:2835-2840 doi:10.1182/blood-2003-10-3366

14. Le Gac G, Scotet V, Ka C, Gourlaouen I, Bryckaert L, Jacolot S et al (2004) The recently identified type 2A juvenile haemochromatosis gene (HJV), a second candidate modifier of the $\mathrm{C} 282 \mathrm{Y}$ homozygous phenotype. Hum Mol Genet 13:1913-1918 doi: $10.1093 / \mathrm{hmg} / \mathrm{ddh} 206$

15. Le Gac G, Férec C (2005) The molecular genetics of haemochromatosis. Eur J Hum Genet 13:1172-1185 doi:10.1038/sj.ejhg.5201490

16. Lee PL, Gelbart T, West C, Halloran C, Felitti V, Beutler E (2001) A study of genes that may modulate the expression of hereditary hemochromatosis: transferrin receptor-1, ferroportin, ceruloplasmin, ferritin light and heavy chains, iron regulatory proteins (IRP)-1 and -2, and hepcidin. Blood Cells Mol Dis 27:783-802 doi:10.1006/bcmd.2001.0445

17. Livesey KJ, Wimhurst VL, Carter K, Worwood M, Cadet E, Rochette J et al (2004) The 16189 variant of mitochondrial DNA occurs more frequently in $\mathrm{C} 282 \mathrm{Y}$ homozygotes with haemochromatosis than those without iron loading. J Med Genet 41:6-10 doi:10.1136/jmg.2003.008805
18. Merryweather-Clarke A, Pointon JJ, Shearman JD, Robson KJH (1997) Global prevalence of putative haemochromatosis mutations. J Med Genet 34:275-278

19. Merryweather-Clarke AT, Cadet E, Bomford A, Capron D, Viprakasit V, Miller A et al (2003) Digenic inheritance of mutations in HAMP and HFE results in different types of haemochromatosis. Hum Mol Genet 12:2241-2247 doi:10.1093/ hmg/ddg225

20. Milet J, Dehais V, Bourgain C, Jouanolle AM, Mosser A, Perrin $\mathrm{M}$ et al (2007) Common Variants in the BMP2, BMP4, and HJV genes of the hepcidin regulation pathway modulate HFE hemochromatosis penetrance. Am J Hum Genet 81:799-807 doi:10.1086/520001

21. Montosi G, Donovan A, Totaro A, Garuti C, Pignatti E, Cassanelli $\mathrm{S}$ et al (2001) Autosomal-dominant hemochromatosis is associated with a mutation in the ferroportin (SLC11A3) gene. J Clin Invest 108:619-623

22. Nemeth E, Valore EV, Territo M, Schiller G, Lichtenstein A, Ganz $\mathrm{T}$ (2003) Hepcidin, a putative mediator of anemia of inflammation, is a type II acute-phase protein. Blood 101:2461-2463 doi:10.1182/blood-2002-10-3235

23. Papanikolaou G, Sauels ME, Ludwig EH, MacDonald MLE, Franchini PL, Dubé MP et al (2004) Mutation in HFE2 cause iron overload in chromosome 1q-linked juvenile hemochromatosis. Nat Genet 36:77-82 doi:10.1038/ng1274

24. Pietrangelo A (2004) Hereditary hemochromatosis - a new look at an old disease. N Engl J Med 350:2383-2397 doi:10.1056/ NEJMra031573

25. Pietrangelo A (2004) The ferroportin disease. Blood Cells Mol Diseases 32:131-138 doi:10.1016/j.bcmd.2003.08.003

26. Roetto A, Papanikolau G, Politou M, Alberti F, Girelli D, Christakis J et al (2003) Mutant antimicrobial peptide hepcidin is associated with severe juvenile hemochromatosis. Nat Genet 33:21-22 doi:10.1038/ng1053

27. Sanchez M, Bruguera M, Bosch J, Rodes J, Ballesta F, Oliva R (1998) Prevalence of the Cys282Tyr and His63Asp HFE gene mutations in Spanish patients with hereditary hemochromatosis and in controls. J Hepatol 29:725-728 doi:10.1016/S0168-8278 (98) $80252-3$

28. Waalen J, Nordestgaard BG, Beutler E (2005) The penetrance of hereditary hemochromatosis. Best Pract Res Clin Haematol 18:203-220 doi:10.1016/j.beha.2004.08.023

29. Wallace DF, Pedersen P, Dixon JL, Stephenson P, Searle JW, Powell LW (2002) Subramaniam VN. Novel mutation in ferroportin1 is associated with autosomal dominant hemochromatosis. Blood 100:692-694 doi:10.1182/blood.V100.2.692 